\title{
The Role of Folk Music as Cultural Heritage in the Curriculum of Vocational High Schools of Music: Pattern of Azerbaijan-Turkey ${ }^{1}$
}

\author{
Attila ÖZDEK \\ Necmettin Erbakan University, Turkey \\ argor73@hotmail.com
}

\begin{abstract}
Music is one of the most important elements in the transfer of cultural heritage. Especially traditional forms of music are considered to be the chief carriers of cultural heritage because folk music, which jumps to mind at the mention of traditional music, is a sub-division of culture as a genetic cultural nucleus and at the same time involves many other sub-divisions and features of culture. These elements and features can be listed as features of language, speech and dialect in the oral form, and stories, important events, wars, natural phenomena, important people, religion, traditions and customs, clothes, everyday items, daily life, social relationships, agriculture, animal husbandry, hunting, accommodation, architecture, musical instruments etc. mentioned in the lyrics. Apart from the oral structure, instrumental works are also elements of cultural heritage together with the clothes, jewellery, objects etc. used in folk dances which they accompany, and the instruments used in performing theatrical stories and narratives. Such important cultural heritage is expected to occupy a central and prioritized position in the music education systems of societies. Although the use of elements of folk music in the three major headings of music education, namely general, professional and amateur music education and their levels, has been the subject of many studies, especially to what extent this has been fulfilled in our country is open to debate. Though each type and level of music education is open to research, it is thought that general music education and professional music education are the fundamental elements for the system to function properly in a society. It will be an appropriate approach to explain the representations of these types via the general music education in primary education and music teachers conducting this education. In our country, after primary education, or more appropriately after the eight-year education in primary and middle education, prospective music teachers attend fine arts and sports high schools as interim level
\end{abstract}

\footnotetext{
${ }^{1}$ Is produced by utilizing a part of Phd. thesis: "The Position of Folk Music in National Music Education: Case of Turkey and Azerbaijan"
} 
education institutions where professional music education is given at high school level. In other words, individuals who have completed the general music education, one of the two basic dynamics of the system, graduate from these high schools to move to the other important dynamic of the system. From this perspective, it would not be wrong to call fine arts and sports high schools or their equivalents in other countries as the backyard of institutions educating music teachers. When the importance of the institutions that offer music education at high school level is so evident, it is essential to find out to what extent folk music as an element of cultural heritage is included in the curricula of these schools. Therefore, the curricula of fine arts and sports high schools in our country and the curricula of their counterparts in Azerbaijan, that is music colleges, were investigated, compared and contrasted in terms of their folk music content and the situation was questioned through the results that were obtained and the conclusions that were reached.

Key Words: Music education, Folk music, Fine arts and sports high school, Cultural heritage 


\section{Introduction}

Culture is a set of all concrete-abstract products which human beings create along with nature or against nature. Mankind has learned many behaviours such as surviving, eating, sheltering, continuing generations, having fun, feeling sorry and so on through cultural transmissions which they have acquired over time. Even though these cultural transmissions have varied in shape, size, content, and meaning as ages pass by, traditional cultural tenets and transmissions deriving from historical roots have much more special and great sense.

Traditional cultures are undoubtedly vital dynamics which bear genetic cores that come into existence by being filtered through historical processes of countries, and may be as a resource for almost every action to shape the future of that country. Although these dynamics become exposed to a number of changes in accordance with the changing nature of culture over time, it is possible for communities to preserve their own expressions only with the protection of the core elements of traditional cultures.

It is known that the formation of cultural background, or in other words, cultural make up is determined by transfer facilities depending on the factor of time, sociological, political, climatic and geographical factors, and the interaction with other cultures. However, here it is considered to be important to protect and transfer our accumulation dating from past to present. It is also obvious that the factors and interactions mentioned earlier may have effects which might change the cultural make-up negatively.

Given that it is an indisputable fact that the culture of a community has changed depending on various factors over time and has been in an interaction with other cultures, it is impossible to describe a culture as fixed, static, pure and one-dimensional.

What holds communities together and sustains them is the culture of that community itself. Communities are responsible for protecting their own cultures and transferring them to future 
generations, and thus they struggle to achieve both present and future within a social collectivity possessing the spirit of unity. As a Turkish proverb "Grass grows on its roots" stresses, communities cling to the life through their cultural make-up and roots, and only mature over this background. On the other hand, communities which get away from this idea are either corrupted and dispersed, or completely destroyed (Büyükyıldız, 2009: 13).

Culture, nationality and universality each is a two-dimensional concept. At this point it is not possible to speak of a pure culture. Cultures influencing each other can accept and adopt changes which are appropriate to their own structure over time. However, it should be considered as an impossible outcome that the whole world would happen to turn into a single cultural structure (Yahya Kaçar, 2009; 155).

Cultural meaning which is attributed to only two basic terms such as the East and West has reached an impasse full of contradictions in terms of our country. Our struggle to liberate and exist against the West, which we describe as "a monster with one tooth left" has ended up with a paradoxical attempt to be like Westerners. It has been the greatest mistake to associate the West's advanced technology and science with the cultural layers; that's, it has been assumed that some progress can be achieved along with such cultural transplantation.

According to Tunaya, the fact that cultural actions taken as a result of attempts to get free from the Western tendency have been explained with the concept of "Westernization" is a contradiction in itself, but this situation can be best described with the phrase, "Westernization despite the West " as explained. In Turkey, which set an example for many Eastern countries with its struggle against European imperialism, some westernizing reforms entered into force during the struggle for freedom following the Independence War and thus it was attempted to create the Turkish National Identity, which summarizes the process of fighting in a war with the West to become like Westerners (trans.: Sağlam, 2009: 100). 
However, as mentioned, as a result of the idea of Westernization and its practice continuing up to now from the last periods of the Ottoman Empire, that's, since the 1800s, the Turkish society has neither managed to remain as it used to be, or to become Westernized, nor could sufficiently create contemporary values with international validity meeting the national requirements. It has been neglected that Western communities seen as models are not static now as they used to be 200 years ago, and no matter what their socio-cultural and political understanding is, such features as dynamic organism and creative momentum of advanced communities have been overlooked. Traditional and universal values that are required for the realistic development of a culture could not be achieved to incorporate into daily life gain with a contemporary understanding. It was not possible to completely get rid of all kinds of corrupt and conservative elements which do not conform to the dynamic character of our society, and we failed to achieve the goal of reaching the level of contemporary societies with our own way of thinking based on our self resources, without losing our national identity (Sun, 2000: 290; Tanç, 2000: 347).

About twenty years ago Sun (1993: 19), who prepared a report on identifying and analyzing our country's culture-art related issues and producing some relevant solutions, pointed out that thousands of years of cultural heritage was left to disappear, to be forgotten or corrupted; there appeared a society of intellectuals who got alienated from their own culture; the structure of the state was in an unplanned and purposeless condition within an inconsistent policy; the Turkish culture and art which was attempted to be created does not comply with the society; and national awareness of the culture was not ensured. In fact, when these assumptions are re-evaluated under the present circumstances, it seems to be quite difficult to say that we have made considerable progress.

It is considered that answering the questions of when, how and in what way to use traditional accumulation of knowledge, feeding cultural layers, as a vital dynamic in bringing up 
individuals of a particular community becomes an important part of the process of reintegrating the individual into the society. This process which begins in the family continues as systematic and programmed throughout their school life. It is a fact that the culture of a society, which exists and changes/alters depending on such factors as family and school but also staying away from these two, equips individuals with the elements of that culture and feeds these individuals within the "family-school-community culture" triangle.

Within this triad, the family plays a major role in the reproduction of culture as being the best environment to transfer culture from generation to generation. When legal, economic conditions and Turkish society are also taken into consideration, the reproduction of culture in the family continues its interaction with especially moral connections (Büyükyıldı, 2009: 13). On the other hand, school education is of utmost importance in the triad of family, school and culture of the society since the school enables the individual to attain cultural heritage by shaping cultural gains from both the family and society in a disciplined way and thus becomes the most important tool for transfer and exchange of culture.

It is considered impossible to allow for a universal appreciation of the values of the community unless school environment which sustains the process of keeping the national culture alive, transferring, and developing it, that is, the phenomenon of education, is characterized by national qualities. It is known that bearing a national character, education will not only help a remarkably distinctive cultural makeup to be adopted, spread, and disseminated throughout the country but it will also help this distinctive national character contribute greatly to the universal culture and education. For this reason, Western societies have matured the process of national structuring in their education systems along with the nationalist movements. 


\section{Status of the Problem}

The most significant and impressive situation of education and culture relation occurs in education of art since it consists of such a lot of material, written, visual, oral and auditory elements which belong to culture. It is clear that, education of art in this way is very important in terms of individuals' feeling of identity and belongingness related with the society which they live in.

Education of art is the most significant educational dimension which helps students to understand the responsibilities of their society. Art helps them to acquire a social and cultural awareness. Art is the primary of the topics which students study to understand the cultural values and social power sources (Elliot, 1984: 260).

Education of art is composed of facilities and interactions that are structured in order to satisfy an individual's creativeness, meet their aesthetic needs, improve their feeling of appreciation and provide sensitivity towards the realities they experience. So that, in addition to individual's cognitive and psychomotor sides, it is also very important especially in improving affective sides. Education of music is one of the most important elements in art education which is divided into three groups as phonetic, plastic and dramatic arts (Uçan, 1997: 40)

If it is necessary to put the topic into the focus of research, education of art's having a national character is accepted substantial. Since music is a multidimensional aesthetic structure which consists of many vital elements such as language, history, customs and beliefs in addition to its own matters and concepts. Having a national characteristic of such an important point is an indispensible condition for the existence of society, its continuity and improvement.

It is known that, music is a very significant connective element in the triangle of family, school and culture, and the melodies which are learnt in family structured by social culture 
develop a systemized, permanent and regenerating identity itself. At this point, the important thing is learning and teaching folk music which contributes to a national identity both for the person and society; forming new examples / styles from its own cores is also important.

Folk music was accepted as the most substantial source of a national character in music education, and conceptions of music education having national characteristics got their origins from folk music structures which belong to that society. Using especially folk music, was regarded as an important step in education of music and this situation was tried to build on a solid ground by teaching folk instruments, disciplining concepts and features of folk music and also using them in education.

To form a national musical concept, folk melodies that have a national identity are needed to be transferred to school environment which have systematic education opportunities. The origins of national music material which are supposed to be used in school should be based on folk music. Since folk music and examples created by inspiring it are very important music education materials which have positive effects and originality both in cultural development of the personal and cultural identity of the nation.

The materials which are used with the teaching steps that form music education and facilities should benefit from the national musical culture. This point is mentioned by many researchers. In order to provide a healthy musical teaching environment, transferring foreign culture should be avoided; on the other hand, having monotype arbitrariness with an archconservative perspective and ignoring world cultures should also be avoided. It is required to found a system which allows intervention in determined faults, deficiencies and being able to update/ develop if it is necessary.

The most important material that will be used in music education is repertory of melodies. Hence, it is necessary to consider the relationship and consistency of this material with its 
type and education step where it will be used. In other words, the step of education and its type is significant in terms of some technical features (rhythm, sound width, and tonality) and difficulties in melodies. However this situation is not a factor which affects folk music melody in songs or resemblance to them.

Education of music can be regarded as one of the touchstones of struggling for existence in the world because it is not wrong to say that music, which has a lot of functions such as individual, social, economical, cultural and educational, wholly consists of a society's genetic codes. Educating, differentiating and structuring such a significant concept are as much important as music itself.

Education of music, which is identified as purposefully contributing specific musical behaviours to the individual, changing musical behaviours partly or wholly and purposefully improving individual's musical behaviour through his/her own life, has three main types as general, amateur and vocational in terms of its purpose. Individual, with group and mixed of both can be regarded as the determining conditions of music education. It is known that, general music education is mostly done with group and vocational music education is done individually (Uçan, 1997: 8; Uçan, 2001a: 116).

It is considered that, vocational and general music education become prominent in an integrative and healthy music education system and then, amateur music education which is developed dually reaches a specific character by itself. From these prominent concepts, the most common first is a determinative element for a well working system. In terms of our country, the first and most common step of musical education is represented by the Fine Arts and Sports High Schools (FASHS).

For the sake of developing a comparative perspective, the foundations working at a level of high schools in Turkey and Azerbaijan have been dealt with, as it is known that Turkey and 
Azerbaijan have many common points ranging from instruments to modes, from dancing characteristics to the topics, from conventional and musical ceremonies to being a poet. It is certainly accepted that the citizens of these two countries who share common inheritance have tried to express themselves sometimes with same, sometimes with similar and sometimes with different musical preferences. At this point, it is an accepted truth that there is a big similarity and association in conventional music structures.

The other reason why we have chosen Azerbaijan, with whom we have same and similar musical characteristics, for comparison is that national Azerbaijan musical education model is based on a statement which gives more positive results than ours. The work experience of Azerbaijani artists, composers and educators, who have grown up through their own musical education system in many of the countries in the world and especially in our country, has been accepted as a mainstay for this point.

In the light of this information, in the curriculums of vocational high schools of music represented with the FASHS in our country, the questions such as how many academic terms, how many hours in a week and with which content they are given; how important it is in the general curriculum constitute the basic problems of this research. Besides, how the results will be when these parameters are compared with vocational high schools of music in Azerbaijan that have a similar musical culture with us is also the basic problem of this research.

\section{Purpose of the Research}

The main purpose of this research is to analyse and compare programmes of schools which have education at a level of vocational music in Turkey and Azerbaijan in terms of the usage and importance of folk music by explaining how the education of vocational music is planned in Turkey and Azerbaijan in terms of content and extend. 


\section{Planning Vocational Music Education and Vocational High Schools of Music in Turkey and Azerbaijan}

Vocational music education in our country is provided in Fine Arts and Sports High Schools (FASHS), Conservatories, Faculties of Fine Arts (CFFA), Departments of Music Education in Faculties of Education (DMEFE), Band Ncos High Schools (BNHS) and Nco Band Colleges (NBC). It is known that, in FASHSs and BNHSs high school, in NBCs associate degree, in CFFAs and DMEFE s undergraduate and postgraduate vocational music education is supplied. This situation is variable in conservatories: it is determined that most of them only have undergraduate and postgraduate education; however, some have them have also an education at high school level and few of them give primary education.

After candidates complete their four- year high school education in FASHSs which they are placed by special talent examination, they have to attend YGS exam (university entrance exam) which is used in undergraduate placement and get the required minimum passing score, they also have to be successful in the special talent examinations done by foundations they apply. There are no different structuring such as Turkish music-Western music in FASHSs in terms of their education; however, it can be said that the variety of instruments for classical Western music are dominant due to lack of well-educated teachers and content and quality of the applied programme.

In FASHSs, both general high school curriculum and vocational music education are provided. In these schools, except for the fact that lack of well educated teacher staff being responsible to give music lessons is a problem, especially the education of traditional musical instruments still cannot be applied healthily. Curriculums of our traditional instruments which are supposed to be used in FASHSs have not already been wholly completed. Curriculum of "baglama" was wholly completed and approved just a couple of years ago, working on 
curriculums about some instruments such as "oud", "(zither)kanun", "ney", "kemençe", "kaval".

There are three steps of vocational music education in Azerbaijan. These are titled as primordial, middle and lofty. The principals of primordial step are ussag musical schools and schools of fine arts in which music education is conducted at the level of primary school. The schools educating on music at a level of high schools are middle specialisation musical schools, Gymnasia, colleges and techniqums. Lofty musical schools educating at a level of undergraduate and postgraduate are Ince Sanat University, Baku Music Academy, Baku National Conservatory and Pedagogical University (Interview 1).

It is known that, except for seven-year ussag musical schools in Azerbaijan which are at primary level, eleven-year Gymnasia, musical schools and eleven-year vocational music schools are the ones giving vocational music education at high school level. On the other hand, the schools which only educate at a level of high school are four-year musical colleges and techniqums.

The total number of colleges and techniqums at high school level is eight in Azerbaijan. Classical Western Music and Azerbaijan Folk music are used uniformly in the education of students who are chosen among graduates of ussag musical schools in line with physical conditions and opportunities. The students graduated from Classical Western instruments can attend to Bahu Music Academy, the ones graduated from folk music instruments can attend to Ince Sanat University, Baku National Conservatory or Pedagogical University. Graduates can work as a teacher at ussag musical schools if they want (Interview 2).

"Asaf Zeynallı College of Music", which we had an opportunity to observe during our research, accepts nearly three hundred students in a year and divide the students equally between Classical Western Music and Azerbaijan folk music in the line with its opportunities. 
There about three hundred and fifty teachers who have graduated from National Conservatory, Music Academy or Ince Sanat University. From these teachers, one hundred and three of them teach piano, the rest of them teach classical Western and folk music instruments with theoretic lessons. This one hundred and ten year old school gives an education with its three concert halls one of which has two hundred and fifty people and two other ones have seventy five people capacities, fifty five classrooms and a library in the city centre of Baku in an art worthy building. The college has a folk instruments orchestra including sixty people. $25 \%$ of college graduates can continue their undergraduate education, rest of them work as teachers in ussag musical schools in different regions of the country. Some of the graduates make musical groups (ensemble), work in places of musical entertainment or continue education in different fields (Interview 2).

It is understood that, vocational music education in all around Azerbaijan is attempted to be achieved widely, multiple choice, in a way including folk music and qualitatively from primary education to postgraduate education. The remarkable point is starting of vocational music education at primary years and the emphasis and importance of folk music in vocational music schools.

On the other hand, the earliest vocational music education can start in the period of high school, in Fine Arts and Sports High Schools in our country because of the fact that there is nearly no opportunity to have music education at primary years. Education period of these schools that are becoming common is four years and their curriculums' quality and quantity are discussed in academic fields. At the same time, FASHSs are so much important as substructure foundations educating students for DMEFEs which school music teachers who are accepted as a key point for our national music education.

Even though in both countries, there is a difference in institutions educating at high school level, it is thought that the foundations across the country which set up a substructure for the 
programmes schooling music teachers should be considered. Since it is observed that Gymnasia within the conservatory provides training alone, whereas, colleges of music are widespread in country and the candidates graduated from this school apply for the programmes especially schooling music teachers. Though vocational music education at high school level is provided by some conservatories in our country, it is a widely known reality that FASHSs which are common across the country send students to the music teacher training programmes.

\section{Method of Research}

As well as this study has a descriptive research oriented to determine current, it also consists of a qualitative model in which literature review, document review-comparison and partly interview methods have been used. In the part of transnational comparative educational research, quantitative methods have been used.

"Comparative education is interdisciplinary. It analyses different policies on education, laws about education, financial sources and structures (primary education, high school education, higher education) of education. It also analyses all of the questions about purpose, content, methods, tools, education materials, evaluation, teacher, student, director, students' guardians and auditor. It is a field of research which theoretically and practically examines two or more educational systems in different countries and cultures with their similarities and differences.” (Türkoğlu, 1998: 23)

It is an analysing and researching field which determines and comments current education problems and reasons of these problems in societies by mentioning similar factors in other societies." "Comparison of an education system which deeply affects a society with other countries' education systems has found out field of comparative education.” (Kilbaş, 2007: 42)

According to these definitions, our research is "research of comparative music education". 


\section{Research Sample, Collection and Analysis of Data}

Research sample is composed of Turkey and Azerbaijan's pressed written, electronic sources which belong to national education of music and programmes and curriculums of vocational music schools in these two countries.

In order to get data about research, some methods such as compiling periodical- non periodical, pressed written and electronic sources which have scientific quality and can be reached in Turkish, Azerbaijani and English languages are used. In addition to this, analysis have been done in related vocational music schools for ten days in Baku, source, document, curriculum and course books have been gathered and some semi-structured interviews have been made with some directors and educators.

The data of research have been compared with structures of vocational music education, programmes and curriculums of vocational music education institutions at high school level and value and importance situations in their contents in folk music by compiling qualitative and quantitative findings with interview data.

\section{Findings}

When considered from the perspective of our country, FASHS are an institution serving as a base both for representing the first, common and general, step of vocational music education and for training students for undergraduate programmes which music teachers graduate from, who are one of two main dynamics of the system of music education. Therefore, it is useful to compare the program of the FASHS in our country with that of the College of Music in Azerbaijan, which corresponds to the FASHS in terms of the content of folk music, and in this way it will help the current research produce findings regarding the importance given to the folk music within an understanding of national music education between the two countries, based on this comparison. 
In our country, there are fifty-four FASHS in total, only two of which are found in Izmir and the other fifty-three of which provide education in fifty-three different provinces. Students are accepted for FASHS through a special aptitude test after they have finished their primary school education. An instrument which will be trained on during eight terms is chosen for each candidate, who has a right to be a student in this school by being successful in this exam, considering the student's own preferences, their physical properties, and the number of teachers. As shown in Table 1, the student takes a course on this instrument, called "Turkish and Western Musical Instruments". Moreover, all the other students follow the same program. In secondary schools in our country, a yearly work calendar is planned by a total of 36 weeks. For this reason, hours included in the column of Total Course Hour (TCH) are obtained by first multiplying the weekly total number of lessons of that course for each academic year by a total of 36 weeks and then summing the values of each year up.

Table 1

4-Year Curriculum of Departmental Courses Conducted in FASHS in Our Country

\begin{tabular}{|c|c|c|c|c|c|c|c|c|c|}
\hline \multirow{3}{*}{ Departmental Courses } & \multicolumn{8}{|c|}{ Years/Terms } & \multirow{3}{*}{$\begin{array}{c}\mathbf{T C} \\
\mathbf{H}\end{array}$} \\
\hline & \multicolumn{2}{|c|}{9} & \multicolumn{2}{|c|}{10} & \multicolumn{2}{|c|}{11} & \multicolumn{2}{|c|}{12} & \\
\hline & $\mathbf{I}$ & II & $\begin{array}{l}\text { II } \\
\text { I }\end{array}$ & $\begin{array}{c}\mathbf{I} \\
\mathbf{V}\end{array}$ & $\mathbf{V}$ & $\begin{array}{l}\mathbf{V} \\
\mathbf{I}\end{array}$ & $\begin{array}{c}\text { VI } \\
\text { I }\end{array}$ & $\begin{array}{l}\text { VI } \\
\text { II }\end{array}$ & \\
\hline MUSICAL HEARING, READING & 1 & 1 & 4 & 4 & 4 & 4 & 4 & 4 & 468 \\
\hline PİANO & 1 & 1 & 2 & 2 & 2 & 2 & 3 & 3 & 288 \\
\hline TURKISH AND WESTERN MUSIC & 1 & 1 & 2 & 2 & 2 & 2 & 3 & 3 & 288 \\
\hline TURKISH MUSIC CHOIR & 1 & 1 & 2 & 2 & 3 & 3 & 3 & 3 & 324 \\
\hline WESTERN MUSIC CHOIR & 1 & 1 & 2 & 2 & 3 & 3 & 3 & 3 & 324 \\
\hline DRAMA & - & - & 1 & 1 & - & - & - & - & 36 \\
\hline INTRODUCTION TO MUSIC & 1 & 1 & - & - & - & - & - & - & 36 \\
\hline MUSIC STYLES & - & - & - & - & - & - & 1 & 1 & 36 \\
\hline TURKISH AND WESTERN & - & - & - & - & 4 & 4 & 4 & 4 & 288 \\
\hline HISTORY OF WESTERN MUSIC & - & - & - & - & 1 & 1 & - & - & 36 \\
\hline TRADITIONAL TURKISH MUSIC & - & - & - & - & - & - & 1 & 1 & 36 \\
\hline
\end{tabular}




\begin{tabular}{|l|c|c|c|c|c|c|c|c|c|}
\hline INFORMATION TECHNOLOGIY & - & - & - & - & 1 & 1 & - & - & 36 \\
\hline INDIVIDUAL VOICE TRAINING & - & - & - & - & - & - & 1 & 1 & 36 \\
\hline INSTRUMENT MAINTENANCE & - & - & - & - & - & - & 2 & 2 & 72 \\
\hline ELECTIVE COURSES & - & - & 5 & 5 & 2 & 2 & 2 & 2 & 324 \\
\hline
\end{tabular}

According to Table 1, the curriculum of FASHS puts great emphasis on hearing, piano, instrument training, choir education of Turkish and Western music, and musical instruments. In addition, elective courses hold a significant place within the curriculum. As understood from the curriculum, education on the traditional music is mainly provided through the courses of "Turkish Music Choir Training”, "Turkish and Western Classical Music Chamber Orchestras" and "Traditional Turkish Music History". In addition, in the courses of "Musical Hearing, Reading and Writing", "Piano", "Music Styles" and "Instrument Maintenance and Repair", it is deemed appropriate to have allocated time for our traditional music and instruments in the content and practice as well, depending on the teacher's initiative.

According to this situation, the students receive as much training of "Piano" as individual instrument training, and "Western Music Choir Training "as much as they take "Turkish Music Choir Training”, and they can only have a four hour-course of chamber orchestras in a week during the last four terms and also an hour of "Traditional Turkish Music History" in the last two terms. It is evident from the content of the curriculum that it lacks any theoretical or applied courses directly relating the folk music. In contrast, some content regarding the folk music should be thought to be found in the courses of "Turkish Music Choir Training", "Turkish and Western Musical Chamber Orchestras" and "Traditional Turkish Music History".

It has been stated that elective courses in the curriculum of the FASHS can be chosen from common courses in the programme or departmental courses, as a requirement of the relevant regulations. In that case, the choice may vary in every high school, and even though courses 
elected might be those on our traditional music, it is realized that a course directly concerning folk music cannot be included in the program anyway. However, when the total hour of elective courses is considered, it is noteworthy that they are attached most weight in the curriculum.

The structure of Azerbaijani music colleges at the level of a four-year high school, which might be thought to correspond to the FASHS, is different from that of our country. Throughout Azerbaijan, vocational music training in such four different fields as "Folk Musical Instruments", "Fortepiano", "Singing Art" and "Orchestral Instruments" is provided in almost 10 music colleges. Other departmental courses excluded from the common high school curriculum vary according to these four basic fields.

According to the work schedule of the music college in Azerbaijan, although it changes from term to term, a period of 40 weeks in the first year; 37 in the second and third year; and 34 in the fourth year is followed. According to these figures, the Total Hours (TDS) for each course in the program are shown in the relevant column.

As seen in Table 2, it is understood that in the program of a basic field "Folk Musical Instruments" of the music college, compared to the total weight of the hearing and theory courses which we can view as core courses of music education, "World Folk Music Literature" hold an important place; a total of 106 hours is allocated for a course called "Azerbaijan Music Literature"; courses of "Specialist", "Mugam" and "Orchestra Class" reach a considerable period in terms of allotted hours in total; 176 hours for "Ensemble Class" and 74 for "Folk Musical Instruments Tedris Metodika" are allocated.

As the program belongs to the basic field of Folk Musical Instruments, it is natural to make space for the world and Azerbaijani folk music in the curriculum. 
Elective courses have been allotted a period of 371 hours in total and as far as understood from the relevant documents, these courses may be selected from among "Mugam History",

"Piano Music Works", "Similar to The Learning of Musical Instruments", "Partition Recitations" and "Transposition and Orchestration".

Table 2

Basic Field Program of Folk Instruments in Azerbaijan Music College

\begin{tabular}{|c|c|c|c|c|c|c|c|c|c|c|}
\hline & \multirow[b]{2}{*}{ Departmental Courses } & \multicolumn{8}{|c|}{ TERMS } & \multirow{2}{*}{$\begin{array}{c}\text { TC } \\
\mathbf{H}\end{array}$} \\
\hline & & I & II & III & IV & $\mathbf{V}$ & VI & $\begin{array}{l}\text { VI } \\
\text { I }\end{array}$ & $\begin{array}{l}\text { VII } \\
\text { I }\end{array}$ & \\
\hline \multirow{7}{*}{ 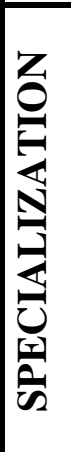 } & FUNDAMENTALS OF & 2 & 2 & 2 & - & - & - & - & - & 116 \\
\hline & HARMONY & - & - & - & 2 & 2 & 2 & 2 & - & 146 \\
\hline & SOLFEGGIO & 2 & 2 & 2 & 2 & 3 & 3 & 3 & 3 & 367 \\
\hline & WORLD FOLK MUSIC & 2 & 3 & 2 & 3 & 3 & 3 & 3 & 3 & 407 \\
\hline & AZERBAIJAN MUSIC & - & - & - & - & - & 2 & 2 & 2 & 106 \\
\hline & PRINCIPLES OF & - & - & 2 & 2 & - & - & - & - & 74 \\
\hline & ELECTIVE COURSES & - & - & 1 & 1 & 3 & 3 & 1 & 3 & 216 \\
\hline & SPECIALIZATION & 2 & 2 & 2 & 2 & 3 & 3 & 3 & 3 & 367 \\
\hline & MUGAM & 2 & 2 & 2 & 2 & 3 & 3 & 3 & 3 & 367 \\
\hline & ORCHESTRA CLASS & - & - & 2 & 2 & 4 & 4 & 6 & 6 & 426 \\
\hline & ENSEMBLE CLASS & - & - & - & - & 2 & 2 & 3 & 3 & 176 \\
\hline & FOLK MUSICAL & - & - & 2 & 2 & - & - & - & - & 74 \\
\hline & CONDUCTING & - & - & - & - & 1 & 1 & 2 & 2 & 104 \\
\hline & ELECTIVE COURSES & - & - & - & - & 2 & - & 4 & 3 & 155 \\
\hline
\end{tabular}

Table 3 examines the eight-term program of another basic field, "Fortepiano" of the music college. Here again, while the basic theory and hearing lessons hold an important place, it is seen that "World Folk Music Literature" and "Fortepiano" classes are alloted quite significant periods of time; a total of 180 hours is provided for courses of "Azerbaijan Music Literature" and "Mugam History" with regard to folk music, and elective courses occupy 516 hours in 
total in the curriculum. Elective courses which a considerable amount of time is allotted for can be chosen from "Public Creativity", "Fundamentals of Azerbaijan Folk Music", "Science of Instruments", "Analysis of Musical Works", "History of the Fortepiano Art", and "The Essence of Reading”. It is noteworthy that those with content of folk music have gained an important weight among elective courses.

Table 3

Basic Field Program of Fortepiano in Azerbaijan Music College

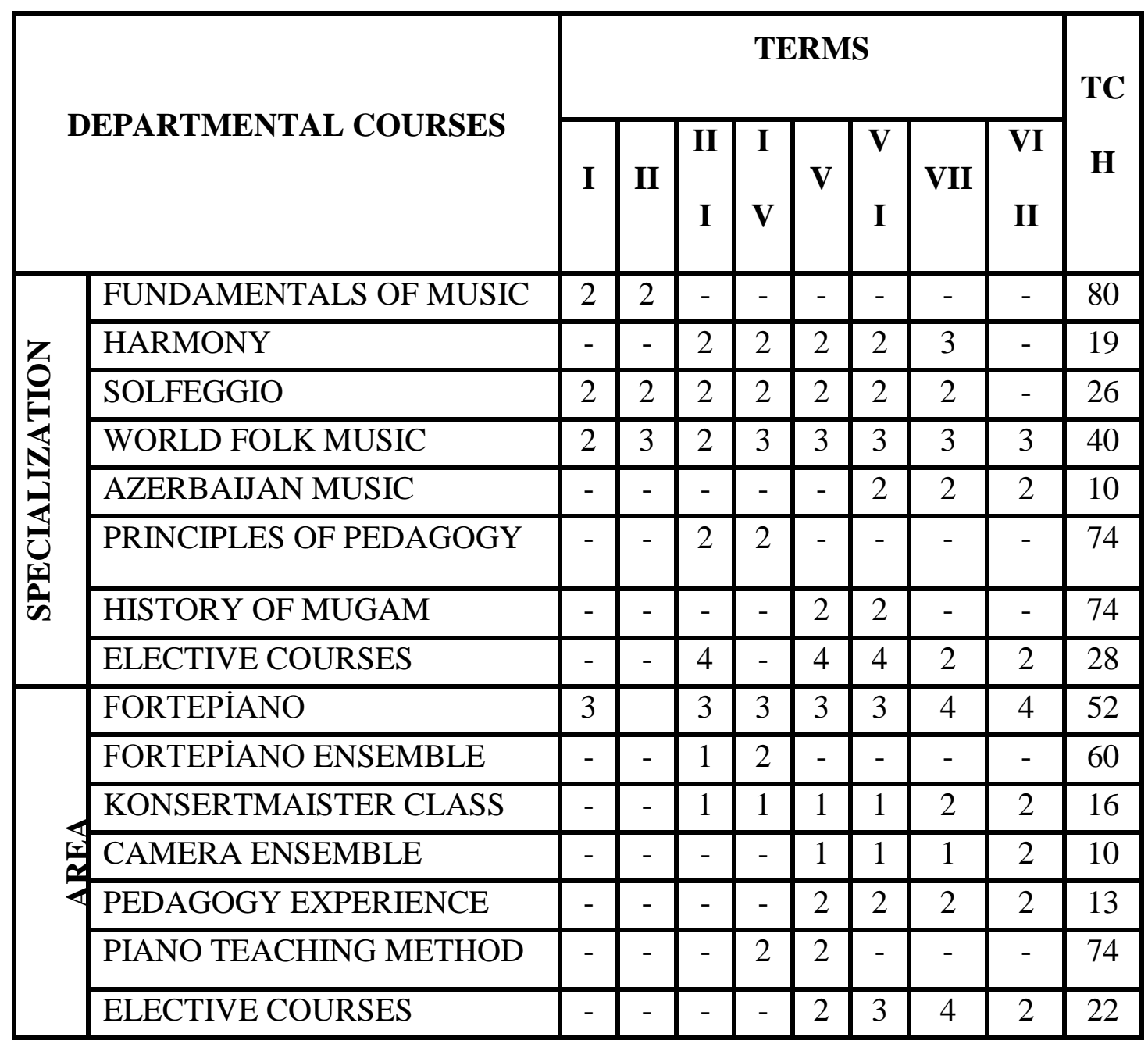

According to Table 4, it is seen that the basic field of "Singing Art" in the music college covers a 3-year period in total, and along with the theory and hearing classes "World Folk Music Literature", "Solo Performance" and "Choir Class" have an important role in the programme. 
One more time, "Azerbaijan Music Literature" is included in the program, with a 106-hour period. Electives which cover a total of 528 hours can be selected from those; "Mugam History”, “Azerbaijan Folk Music Works", "Public Creativity", “Writing”, "Analysis of Musical Works", "Relationship of Aruz Prosody with Mughams" and "Vocalizing Azerbaijani Folk Songs". It is quite remarkable to point out the proportion of folk music content in elective courses.

Table 4

Basic Field Program of Singing Art in Azerbaijan Music College

\begin{tabular}{|c|c|c|c|c|c|c|c|c|c|c|}
\hline \multicolumn{2}{|c|}{ DEPARTMENTAL COURSES } & \multicolumn{8}{|c|}{ TERMS } & \multirow{2}{*}{$\begin{array}{r}\text { TC } \\
\mathbf{H} \\
110\end{array}$} \\
\hline \multirow{7}{*}{ 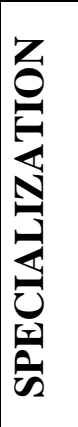 } & MUSIC EXECUTIVE & $\begin{array}{l}\text { I } \\
-\end{array}$ & $\begin{array}{l}\text { II } \\
-\end{array}$ & $\begin{array}{l}\text { III } \\
4 \\
\end{array}$ & $\begin{array}{l}\text { IV } \\
2\end{array}$ & $\begin{array}{l}\mathbf{V} \\
-\end{array}$ & $\begin{array}{l}\text { VI } \\
-\end{array}$ & $\begin{array}{c}\text { VI } \\
\text { I } \\
-\end{array}$ & $\begin{array}{c}\text { VII } \\
\text { I } \\
-\end{array}$ & \\
\hline & FUNDAMENTALS OF & - & - & - & 2 & 2 & 2 & 2 & - & 146 \\
\hline & HARMONY & - & - & 5 & 5 & 3 & 3 & 2 & 2 & 364 \\
\hline & SOLFEGGIO & - & - & 4 & 5 & 3 & 3 & 3 & 3 & 380 \\
\hline & WORLD FOLK MUSIC & - & - & - & - & - & 2 & 2 & 2 & 106 \\
\hline & AZERBAIJAN MUSIC & - & - & 2 & 2 & - & - & - & - & 74 \\
\hline & ELECTIVE COURSES & - & - & - & - & 4 & 4 & 4 & 4 & 284 \\
\hline & SOLO PERFORMANCE & - & - & 4 & 4 & 4 & 4 & 4 & 4 & 432 \\
\hline & CHOIR CLASS & - & - & 2 & 2 & 2 & 2 & 2 & 2 & 216 \\
\hline & ACTING ART & - & - & 2 & 2 & 2 & 2 & - & - & 148 \\
\hline & STAGE PREPARATION & - & - & - & - & 2 & 2 & 2 & 2 & 142 \\
\hline & NİTQ CIVILIZATION & - & - & 1 & 1 & 1 & 1 & - & - & 74 \\
\hline & MUSIC AL TUNE AND & - & - & - & - & - & 2 & 2 & 2 & 106 \\
\hline & ELECTIVE COURSES & - & - & - & - & 2 & 2 & 5 & 5 & 244 \\
\hline
\end{tabular}

According to Table 5, as in the other three areas in the music colleges, the allocated time for the hearing and theory courses also seems important in the basic field of "Orchestral Instruments". Besides, it is also seen that considerable time is allotted for "World Folk Music 
Literature", "Specialization Area", "Orchestra Class" and "Ensemble Class"; when "Azerbaijan Music Literature" and "Mugam History" courses are examined in terms of the importance to folk music which they give, they cover a 180-hour period; and the course "Fortepiano" is given a period of 148 hours. As in the other three areas, electives reach a significant volume with a total of 572 hours. These courses can be chosen from "Public Creativity", "Fundamentals of Azerbaijan Folk Music", "Writing”, “Analysis of Musical Works", "Developmental History of Orchestral Instruments", "Partition Pronunciation", “Transposition and Orchestration" and "Conducting”. Options for folk music within elective courses are noteworthy one more time.

Table 5

Basic Field Program of Orchestra Instruments in Azerbaijan Music Colleges

\begin{tabular}{|c|c|c|c|c|c|c|c|c|c|c|}
\hline \multirow{2}{*}{\multicolumn{2}{|c|}{ DEPARTMENTAL COURSES }} & \multicolumn{8}{|c|}{ TERMS } & \multirow{2}{*}{$\begin{array}{r}\text { TC } \\
\mathbf{H}\end{array}$} \\
\hline & & $\mathbf{I}$ & II & III & IV & $\mathbf{V}$ & VI & $\begin{array}{c}\text { VI } \\
\text { I }\end{array}$ & $\begin{array}{c}\text { VII } \\
\text { I }\end{array}$ & \\
\hline & FUNDAMENTALS OF & 2 & 2 & - & - & - & - & - & - & 80 \\
\hline & HARMONY & - & - & 2 & 2 & 2 & 2 & 3 & - & 19 \\
\hline & SOLFEGGIO & 2 & 2 & 2 & 2 & 2 & 2 & 2 & - & 25 \\
\hline 4 & WORLD FOLK MUSIC & 2 & 3 & 2 & 3 & 3 & 3 & 2 & 4 & 40 \\
\hline & AZERBAIJAN MUSIC & - & - & - & - & - & 2 & 2 & 2 & 10 \\
\hline & PRINCIPLES OF & - & - & 2 & 2 & - & - & - & - & 74 \\
\hline & FORTEPİANO & 1 & 1 & 1 & 1 & 1 & 1 & 1 & 1 & 14 \\
\hline 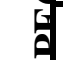 & MUGAM HISTORY & - & - & - & - & 2 & 2 & - & - & 74 \\
\hline & ELECTIVE COURSES & - & - & - & - & 4 & 2 & 4 & 6 & 28 \\
\hline & SPECIALIZATION & 2 & & 2 & 2 & 3 & 3 & 3 & 3 & 40 \\
\hline & ENSEMBLE CLASS & - & - & 2 & 2 & 2 & 2 & 2 & 2 & 24 \\
\hline & ORCHESTRA CLASS & - & - & 2 & 2 & 2 & 2 & 6 & 6 & 40 \\
\hline a & TEACHING METHOD OF & - & - & 2 & 2 & - & - & - & - & 74 \\
\hline & PEDAGOGIC EXPERIENCE & - & - & - & - & 2 & 2 & 2 & 2 & 13 \\
\hline & ELECTIVE COURSES & - & - & - & - & 3 & 3 & 5 & 5 & 28 \\
\hline
\end{tabular}


To summarize, when the FASHS in our country are compared with the music colleges in Azerbaijan, it is noticed that specialization oriented vocational music education is provided in four different areas. In all of the education provided in these areas, courses on instruments are assigned more time compared to the FASHS. As far as the subject of our research is concerned, it is possible to mention that one of those basic areas is already allocated to folk music instruments, and also in general, basic and elective courses relating the folk music are more abundantly found in the program in terms of name, structure, duration and content.

Another striking point is the period of time allotted for the pedagogical courses in the program of the students in the music college who have the quality to do the teaching in some professional music training institutions at the lower level when they graduate despite the fact that they are graduates of the secondary level.

Furthermore, this case shows us the status, position, and importance of the folk music within the curriculum content of vocational music education institutions at the secondary level which lay a foundation for the programmes training music teachers, who we accept are one of two main dynamics in the understanding of national music. Compared with our country, this case in Azerbaijan is understood to be at quite satisfactory levels.

\section{Conclusion}

Music is one of the most important elements and tools of traditional culture system. It is both an essence sustaining traditional cultural structure with its own dynamics and a tool providing its protection and transfer. Continuity, protection and transfer of unique and national cultural texture through music are possible. Folk music, on the other hand, is a type of music symbolising national cultural texture thanks to its characteristics.

Structuring music education on folk music consists of opportunities of protecting and improving the culture as well as having characteristics of cultural ownership, sustentation of 
culture and transferring. Because of this, many countries in the world have structured their music education model according to this understanding.

National music education model accepts folk music as starting point. In addition, it points out a system which includes other cultures, uses all steps of vocational music education according to necessities of time by starting early vocational music education in structuring and forming and also foresees running with the help of qualified and innovative music educators and programmes

Even though education of music is analysed under three main titles as general, volunteer and vocational, main dynamics of a country's music education system have been accepted as general and occupational music education. Because general music education have an effect across the country; on the other hand, vocational music education raises individuals who will run general, volunteer and vocational music education of country. Namely, volunteer music education is directly up to both substructures provided by general music education and also knowledge, accumulation and equipment of educators who have received vocational music education; so that, if general and vocational music educations are healthily provided in a country, it may not be possible to have a problem in volunteer music education.

It is seen as true that, from the two dynamics of music education system, general music education can be associated with primary music education; vocational music can be associated with music teachers that will run education of music. From this point, comparative analysis related with position, location, importance and usage of folk music in music teacher training programmes have been done in general music education programmes, vocational music education programmes at high school level which are under music teacher training stage.

These points below have been determined: 
Anadolu Journal of Educational Sciences International, Art Education Special Issue, November 2015

-Vocational music education in our country is provided in Fine Arts and Sports High Schools (FASHS), Conservatories, Faculties of Fine Arts (CFFA), Departments of Music Education in Faculties of Education (DMEFE), Band Ncos High Schools (BNHS) and Nco Band Colleges (NBC). From these schools, in FASHSs and BNHSs high school, in NBCs associate degree, in CFFAs and DMEFEs undergraduate and then postgraduate vocational music educations are supplied. Even though this situation is variable in four year conservatories, mostly only undergraduate and postgraduate educations are provided; however, some have them have also a four year education at high school level and few of them give primary education.

-If it is analysed in terms of content and extent, it is seen that vocational music education is provided with normal high school curriculum and folk music is supplied with some problems in fifty four FASHSs.

-Vocational music education in Azerbaijan is composed of three steps as primordial, middle and lofty; principals of primordial step educating at primary level are ussag musical schools and schools of virtu arts which have six, seven and seven year education periods; the schools educating on music at a level of high schools are four year middle specialisation musical schools, Gymnasia, colleges and techniqums; lofty musical schools educating at a level of undergraduate and postgraduate are Ince Sanat University, Baku Music Academy, Baku National Conservatory and Pedagogical University.

- The institutions only providing vocational music education at high school level are four year colleges and techniqums; the number of them is eight in Azerbaijan; Classical Western Music and Azerbaijan Folk music are used uniformly in colleges and techniqums.

- FASHS syllabus is prepared according to a thirty six week period; except for major area courses in common high school syllabus, audience, piano, education of playing instrument, Turkish and Western music chorus education and instrument groups are mainly placed; 
selective lessons also have important emphasis; there is no direct lesson about folk music in programme, but education associated with traditional music is done via "Turkish Music Chorus Education", "Instrument Groups of Turkish and Western Music" and "History of Traditional Turkish Music" lessons.

- In four-year colleges of music at high school level which can be considered as counterparts of FASHS in Azerbaijan, musical education is provided in four different areas as "Folk Music Instruments", "Forte piano", "Formerly singing Turkish classical music as a profession" and "Orchestra Instruments"; the major area courses which are not in the programmes of common high school are partly verified according to these four different areas; despite changing in every semester according to working schedule, in the first year forty, in the second year thirty seven and in the fourth year thirty four week periods are applied; besides the total density of audience and theory courses that are the principal courses of music education, a considerable period is given in total for the "Literature of World Folk Music" and "Literature of Azerbaijan Folk Music" in music colleges no matter what the area is; History of Mugam courses are done in specific periods in curriculum according to the field; there is a quite important period in every four fields; selective courses are mostly composed of Azerbaijan folk music topics.

- When FASHSs and music college programmes are compared, it is seen that, in colleges of music, vocational music education is provided in four different areas which are oriented to specialisation; much more time is given for playing instrument courses in all these courses compared to FASHSs; in terms of our research, one of the main areas has already been spared for folk music instruments; in general main and selective courses related with folk music have bigger place in terms of name, structure, time and content; even though being high school graduated, determined time has been spared for pedagogic formation in the programmes of music colleges students who are authorised to be teacher in vocational music education schools at sub stages if they graduate. 


\section{Implications}

-Vocational music education institutions which are becoming popular day by day in our country should be reorganised by considering programmes in FASHSs, folk music and instruments.

-Classroom sizes should be uniformly divided between traditional music instruments and Classical Western Music instruments.

-Selective lessons should be restructured by means of using in a longer period and optionally.

-Course hours and periods about our traditional music should be increased and if necessary, branching in FASHSs should be done by considering diversity of musical education institutions.

\section{References}

Büyükyıldız, H. Z. (2009). Türk Halk Müziği-Ulusal Türk Müziği. Papatya Publishing. İstanbul

Elliot, W. E. (1984). Alternative Approaches to Curriculum Development in Art Education. Studies in Art Education. A Journal of Issues and Research Vol. 25. No. 4 (Summer, 1984), pp. 259-264. Published by: National Art Education Association. ABD

Kılbaş, M. (2007). Türkiye ile Avrupa Birliği Ülkelerinde Müzik Öğretmeni Yetiştirme Programlarının Karşılaştırılması (Almanya, Avusturya ve Polonya Örneği). MA Thesis. Marmara University. Institue of Educational Sciences. İstanbul

Sağlam, A. (2009). Türk Musiki/Müzik Devrimi. Publishing of Alfa Aktüel. Bursa 
Sun, M. (1993). “Kültür ve Düşünce Yaşamımızın Genel Sorunları-Batılılaşma Sürecinde Türk Kültür ve Yaşamının Üç Olgusu-Çözüm Yolları (17-67).” Türk Kalarak Çağdaşlaşma-Türkiye'nin Kültür Sanat Sorunları. Authors: Muammer Sun-Murat Katoğlu. Müzik Ansiklopedisi Publishing. Odak Ofset. Ankara

Sun, M. (2000). Türk Toplumun Müzik Sorunlarının Çözümünde Temel Görüş Ne Olmalıdır? (285-292). Türk Halk Müziğinde Çeşitli Görüşler. der: Salih Turhan. Publications of the Ministry of Culture. 2nd Ed. Cukurova Printing House. Ankara

Tanç, C. (2000). Müzik-Toplum Etkileşimi (344-347). Türk Halk Müziğinde Çeşitli Görüşler. der: Salih Turhan. Publications of the Ministry of Culture. 2nd Ed. Cukurova Printing House. Ankara

Türkoğlu, A. (1998). Karşılaştırmalı Eğitim: Dünya Ülkelerinden Örneklerle. Baki Bookstore. Adana

Uçan, A. (1997). Müzik Eğitimi, Temel Kavramlar-İlkeler-Yaklaşımlar. Müzik Ansiklopedisi Publishing. 2nd Ed. Adalet Printing House. Ankara

Uçan, A. (2001a). Ülkemizde Müzik Öğretimine Genel Bir Bakış (115-133). Müzik Öğretimi, Haz.: Ahmet Say. Müzik Ansiklopedisi Publishing. 3rd Ed. Sözkesen Printing House. Ankara

Yahya Kaçar, G. (2009). Türk Mûsikîsi Üzerine Görüşler (Analiz ve Yorumlar). Maya Akademi Publishing. BRC Printing House. Ankara

\section{Interviews}

Interview 1: Dean of the Undergraduate Division of the National Conservatory of Baku (February. 2008) 
Anadolu Journal of Educational Sciences International, Art Education Special Issue, November 2015

Interview 2: Asaf Zeynallı Music College-Director. Nazim Kazımova (February. 2008) 